\title{
PENGARUH TERAPI RELAKSASI OTOT PROGRESIF TERHADAP TINGKAT STRES PADA LANSIA DI RW 23 KELURAHAN MELONG
}

\section{Khrisna Wisnusakti}

Fakultas Ilmu dan Teknologi Kesehatan Unjani, Indonesia

Email: khrisnaws@gmail.com

\begin{abstract}
Abstrak
Lanjut usia (lansia) di seluruh dunia diperkirakan mencapai 500 juta dengan usia rata-rata 60 tahun. Indonesia sebagai negara berkembang menempati urutan ke-4 dengan jumlah penduduk terbanyak di dunia. Tujuan penelitian ini dilakukan yaitu untuk mengetahui pengaruh terapi relaksasi otot progresif terhadap tingkat stres pada lansia Provinsi Jawa Barat. Penelitian ini menggunakan metode kuisioner untuk mengetahui tingkat stres pada lansia dengan menggunakan Perceived Stress Scale (PSS 10). Skor PSS diperoleh dengan reversing responses (sebagai contoh $0=4,1=3,2=2,3=1,4=0$ ) terhadap empat soal yang bersifat positif (pertanyaan $4,5,7,8$ ). Pada penelitian ini dilakukan uji normalitas data dengan menggunakan Shapiro Wilk dan diperoleh hasil bahwa Pvalue pre test dan post test $(0,318$ dan $0,824)>$ alpha 0,05 . Hal ini menunjukan bahwa distribusi data normal sehingga analisis bivariat menggunakan $\mathrm{t}$ test dependen.
\end{abstract}

Kata Kunci: lansia; terapi; relaksasi otot progresif

\section{Abstract}

The world's elderly are estimated at 500 million with an average age of 60 . Indonesia as a developing country ranks 4th with the largest population in the world. The purpose of this study was to find out the effect of progressive muscle relaxation therapy on stress levels in the elderly of West Java Province. This study used a questionnaire method to determine the level of stress in the elderly by using perceived stress scale (PSS 10). Pss scores are obtained by reversing responses (for example $0=4.1=3,2=2,3=1,4=0$ ) against four positive questions (question 4,5,7,8). In this study, data normality tests were conducted using Shapiro Wilk and obtained the results that Pvalue pre test and post test (0.318 and 0.824) >alpha 0.05. This shows that the distribution of data is normal so that bivariate analysis uses a dependent test.

Keywords: elderly; therapy; progressive muscle relaxation

\section{Pendahuluan}

Lanjut usia (lansia) di seluruh dunia diperkirakan mencapai 500 juta dengan usia rata-rata 60 tahun (Wahyuni \& Ambarwati, 2016). Indonesia sebagai negara berkembang menempati urutan ke-4 dengan jumlah penduduk terbanyak di dunia. Berdasarkan hasil Survey Sosial Ekonomi Nasional (Susenas) tahun 2014, jumlah lansia

$\begin{array}{ll}\text { How to cite: } & \text { Wisnusakti. S (2021). Pengaruh Terapi Relaksasi Otot Progresif Terhadap Tingkat Stres pada Lansia } \\ & \text { Di RW } 23 \text { Kelurahan Melong. Syntax Literate: Jurnal Ilmiah Indonesia, 6(1). } \\ \text { E-ISSN: } & \text { 2548-1398 } \\ \text { Published by: } & \text { Ridwan Institute }\end{array}$


di Indonesia mencapai 20,24 juta orang atau sekitar 8,03\% dari seluruh penduduk Indonesia. Data tersebut menunjukan peningkatan jika dibandingkan dengan tahun 2010 yaitu 18,1 juta orang atau 7,6\% dari total jumlah penduduk. Jawa Barat merupakan provinsi ke 5 dengan lansia terbanyak dengan jumlah 7,09\% dari total penduduk di Jawa Barat (Depkes, 2016).

Seiring meningkatnya derajat kesehatan dan kesejahteraan penduduk akan berpengaruh pada peningkatan Usia Harapan Hidup (UHH) di Indonesia. Berdasarkan laporan Perserikatan Bangsa Bangsa (PBB) 2011, pada tahun 2000-2005 UHH adalah 66,4 tahun (dengan persentase populasi lansia tahun 2000 adalah 7,74\%), angka ini akan meningkat pada tahun 2045-2050 yang diperkirakan UHH menjadi 77,6 tahun (dengan persentase populasi lansia tahun 2045 adalah 28,68\%). Begitu pula dengan laporan Badan Pusat Statistik (BPS) terjadi peningkatan UHH (BPS, 2013). Pada tahun 2000 UHH di Indonesia adalah 64,5 tahun (dengan persentase populasi lansia adalah 7,18\%). Angka ini meningkat menjadi 69,43 tahun pada tahun 2010 (dengan persentase populasi lansia adalah 7,56\%) dan pada tahun 2011 menjadi 69,65 tahun (dengan persentase populasi lansia adalah 7,58\%) (Depkes, 2013).

Adanya peningkatan jumlah lansia menyebabkan perlunya perhatian dan tentunya disertai dampak lebih banyak terjadinya beberapa gangguan pada lansia. Lansia akan mengalami berbagai perubahan fisik, sosial dan psikologis (Hidayati, 2009). Sejalan dengan perubahan tersebut pada fase lansia ini akan lebih mudah menimbulkan rasa cemas, depresi, mudah tersinggung dan kebingungan (Nugroho, 2008). Pada usia ini seringkali lansia melaporkan bahwa tubuhnya tidak sehat, perasaannya tidak tenang terus menerus, penampilan diri menjadi tua, serta merasa kehilangan peran dan status. Sehingga reaksi mereka terhadap gejala ini bermacam-macam. Ada yang sama sekali tidak memperhatikannya sedangkan yang lainnya terlalu memperhatikan dan dianggap sebagai crisis (Suli, Aini, \& Prasetyo, 2019).

Perubahan psikologis seperti bingung, panik, depresif, apatis tidak hanya terjadi pada lansia. Perubahan kesehatan psikologis juga dapat terjadi pada dewasa, remaja bahkan anak-anak. Hal itu biasanya bersumber dari munculnya stressor psikologis paling berat misalnya kematian pasangan hidup dan kematian sanak keluarga dekat (Kartinah \& Sudaryanto, 2008). Perubahan kesehatan psikologis pada masing-masing rentang usia berbeda-beda. Namun perubahan psikologis pada lansia memerlukan perhatian lebih karena kondisi ini yang mengalami penurunan fungsi dibandingkan pada usia yang relatif muda (Hertanto \& Suratini, 2014).

Berdasarkan hasil penelitian yang dilakukan oleh (Suli et al., 2019) tentang aspek sosio-psikologis lansia di Indonesia dijelaskan bahwa perkembangan terakhir manusia ini ditandai oleh berhasil tidaknya tugas perkembangan sebelumnya. Apabila tugastugas tersebut dapat dipenuhi dengan baik, maka dapat diharapkan bahwa di masa lansia individu dapat selalu melakukan penyesuaian terhadap apa yang dihadapinya.

Ketakutan serta gambaran akan keadaan yang semakin parah ditambah dengan menurunnya fungsi yang terdapat dalam tubuh memicu timbulnya pemikiran-pemikiran yang semakin berujung pada keadaan stres (Suli et al., 2019). Namun, disamping itu 
stres dapat juga merupakan faktor pencetus, sekaligus akibat dari suatu gangguan atau penyakit. Faktor-faktor psikososial contohnya perkawinan, masalah orang tua, hubungan interpersonal, pekerjaan, lingkungan hidup, keuangan, hukum, perkembangan, penyakit fisik atau cidera dan faktor keluarga cukup mempunyai arti bagi terjadinya stres pada diri seseorang (Yosep, 2009).

Masyarakat menganggap stres sebagai reaksi terhadap perubahan pada lingkungan yang diakibatkan oleh tekanan yang tidak dapat diatasi serta kurang memperhatikan gejala-gejala yang timbul sehingga mengakibatkan gangguan psikologis. Penerimaan yang kurang baik pada lansia juga dianggap sebagai beban sehingga mendorong keluarga untuk menempatkan lansia di panti sosial tresna werdha. Hal ini menyebabkan terjadinya stres pada lansia karena tidak menerima perubahan lingkungan (Yudi \& Suratini, 2014).

Sebagian besar penduduk lansia di Indonesia hidup bertempat tinggal bersama keluarganya. Namun, di sisi lain terdapat pula panti werdha yaitu suatu institusi hunian bersama dari para lansia. Perbedaan tempat tinggal ini memunculkan perbedaan lingkungan fisik, sosial, ekonomi, psikologis dan spiritual religius (Soejono \& Probosuseno, 2009).

Menurut (Mahfiroh, 2013) dari hasil penelitiannya menjelaskan bahwa stres di sebuah panti werdha dapat dipengaruhi oleh stimulus dari lingkungan eksternal dan internal. Stimulus di lingkungan eksternal yaitu berasal dari luar tubuh lansia atau lebih tepatnya adalah dari kondisi lingkungan tempat tinggal lansia seperti keadaan sosial masyarakat sekitar. Sedangkan stimulus dari lingkungan internal adalah dari dalam diri lansia, yaitu secara psikologis yang berhubungan dengan derajat kesehatan lansia. Hal ini dapat berakibat buruk bagi kesehatan lansia apabila tidak diatasi dengan berbagai upaya salah satunya dengan latihan relaksasi karena dapat memberikan rasa nyaman secara fisik yang akan berpengaruh terhadap kondisi mental lansia (Ashari, 2018).

Ketegangan otot dianggap sebagai gejala stres yang paling umum pada lansia. Keseluruhan efeknya dapat menyebabkan kekauan, nyeri dan ketidaknyamanan. Seiring dengan rangsangan saraf yang berulang, ketegangan otot dapat muncul dalam bentuk sakit kepala akibat tegang, kaku leher, nyeri punggung bawah, kram perut, dan beberapa bentuk sindrom sendi temporomandibular (temporomandibular joint syndrome) (Council, 2010).

Psikofarmaka dan psikoterapi merupakan terapi yang bisa menurunkan tingkat stres. Anti-cemas dan anti-depresi diberikan sebagai terapi medik dan psikoterapi untuk keperawatan jiwanya. Ada beberapa terapi yang dapat digunakan untuk mengurangi tingkat stres, seperti Terapi benson, Terapi Autogenik, Hypnoteraphy, Reminiscence Therapy dan Relaksasi Otot Progresif (Herodes, 2010).

Teknik relaksasi otot progresif merupakan teknik relaksasi otot dalam yang tidak memerlukan imajinasi, ketekunan atau sugesti. Relaksasi otot progresif memusatkan perhatian pada suatu aktivitas otot dengan melakukan teknik relaksasi untuk mendapatkan perasaan relaks. Teknik relaksasi ini mengkombinasikan latihan napas dalam dan serangkaian seri kontraksi dan relaksasi otot. Teknik relaksasi otot progresif 
memungkinkan pasien untuk mengendalikan respon tubuhnya terhadap ketegangan (Wahyuni, 2016).

Dalam penelitian Ari (2010) menyebutkan bahwa relaksasi progresif sebagai salah satu teknik relaksasi otot yang telah terbukti dalam program terapi terhadap ketegangan otot mampu mengatasi keluhan ansietas, stres, insomnia, kelelahan, kram otot, nyeri leher dan pinggang, tekanan darah tinggi, fobia ringan dan gagap. Menurut penelitian (Hertanto \& Suratini, 2014) tentang pengaruh terapi relaksasi progresif terhadap tingkat stres pada lansia, peneliti tersebut mendapatkan hasil penelitian bahwa terdapat pengaruh yang signifikan terhadap pemberian terapi relaksasi progresif terhadap tingkat stres lansia.

Dilihat dari fenomena diatas, penulis tertarik melakukan penelitian tentang "Pengaruh Terapi Relaksasi Otot Progresif Terhadap Tingkat Stres Pada Lansia Di RW 23 Kelurahan Melong.

\section{Metode Penelitian}

A. Rancangan Penelitian

a. Desain Penelitian

Desain yang akan dilakukan dalam penelitian ini adalah Quasi Experiment dengan rancangan one group pretest-posttest design.

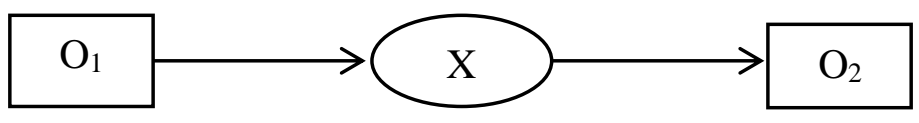

\section{Gambar 1 Rancangan Penelitian}

Keterangan:

(Sumber : (Sugiyono, 2017))

$\mathrm{O}_{1} \quad$ : Tingkat stres pada lansia sebelum dilakukan terapi relaksasi otot progresif

$\mathrm{X} \quad$ : Pemberian terapi relaksasi otot progresif

$\mathrm{O}_{2} \quad$ : Tingkat stres pada lansia setelah dilakukan terapi relaksasi otot progresif

b. Definisi Operasional

Polit dan Beck (2012) memberi gambaran tentang definisi operasional sebagai sesuatu kekhususan yang dilakukan oleh peneliti untuk mendapatkan informasi. "Definisi harus menetapkan bagaimana variable akan diamati dan diukur dengan situasi penelitian yang nyata" (Polit \& Beck 2012). Berikut ini akan diuraikan beberapa definisi (lihat pada tabel 1), dimana setiap definisi akan dikaji atau diukur dalam penelitian ini. 
Tabel 1

Definisi Operasional

\begin{tabular}{|c|c|c|c|c|c|}
\hline Variabel & Definisi Konseptual & $\begin{array}{c}\text { Definisi } \\
\text { Operasional }\end{array}$ & Alat Ukur & $\begin{array}{l}\text { Hasil } \\
\text { Ukur }\end{array}$ & $\begin{array}{c}\text { Skal } \\
\mathbf{a}\end{array}$ \\
\hline $\begin{array}{l}\text { Variabel } \\
\text { Independen } \\
: \quad \text { Terapi } \\
\text { Relaksasi } \\
\text { Otot } \\
\text { Progresif }\end{array}$ & $\begin{array}{l}\text { Terapi Relaksasi Otot } \\
\text { Progresif merupakan } \\
\text { suatu terapi relaksasi } \\
\text { yang diberikan } \\
\text { kepada klien dengan } \\
\text { menegangkan otot- } \\
\text { otot tertentu dan } \\
\text { kemudian relaksasi. } \\
\text { Relaksasi progresif } \\
\text { adalah salah satu cara } \\
\text { dari teknik relaksasi } \\
\text { yang dang } \\
\text { mengombinasikan } \\
\text { latihan napas dalam } \\
\text { dan serangkaian seri } \\
\text { kontraksi dan } \\
\text { relaksasi otot tertentu } \\
\text { menurut Kustanti dan } \\
\text { Widodo dalam } \\
\text { (Setyoadi, 2011). }\end{array}$ & $\begin{array}{l}\text { Terapi Relaksasi Otot } \\
\text { Progresif merupakan } \\
\text { suatu cara untuk } \\
\text { membuat otot-otot } \\
\text { rileks r dengan } \\
\text { mengkontraksikan } \\
\text { dan merileksasikan } \\
\text { otot-otot. Yang } \\
\text { dilakukan selama } 7 \\
\text { kali dalam satu } \\
\text { minggu dengan } \\
\text { durasi waktu } 15-20 \\
\text { menit setiap kali } \\
\text { perlakuannya. }\end{array}$ & $\begin{array}{l}\text { SOP } \\
\text { (Standar } \\
\text { Operasional } \\
\text { Prosedur) }\end{array}$ & - & \\
\hline $\begin{array}{l}\text { Variabel } \\
\text { Dependen : } \\
\text { Stres pada } \\
\text { Lansia }\end{array}$ & $\begin{array}{l}\text { Stres adalah kondisi } \\
\text { yang tidak } \\
\text { menyenangkan } \\
\text { dimana manusia } \\
\text { melihat adanya } \\
\text { tuntutan dalam suatu } \\
\text { situasi sebagai beban } \\
\text { atau diluar batasan } \\
\text { kemampuan mereka } \\
\text { untuk memenuhi } \\
\text { tuntutan tersebut } \\
\text { (Nasir, 2011). }\end{array}$ & $\begin{array}{lr}\text { Stres merupakan } \\
\text { reaksi fisiologis dan } \\
\text { psikologis yang } \\
\text { terjadi apabila } \\
\text { seseorang merasakan } \\
\text { ketidakseimbangan } \\
\text { antara tuntutan yang } \\
\text { dihadapi dengan } \\
\text { kemampuan untuk } \\
\text { mengatasi tuntutan } \\
\text { tersebut. }\end{array}$ & $\begin{array}{l}\text { Kuisioner } \\
\text { Stres } \\
\text { Perceived } \\
\text { Stress Scale } \\
\text { (PSS-10) }\end{array}$ & $\begin{array}{ll}\text { a. } & \text { skor 1- } \\
& 14 \\
\text { b. } & \text { skor } \\
& 15-26 \\
\text { c. } & \text { skor } \\
& 26-40 \\
& \text { (Cohen } \\
& , 1983)\end{array}$ & $\begin{array}{l}\text { Inter } \\
\text { val }\end{array}$ \\
\hline
\end{tabular}

c. Populasi dan Sampel

Populasi pada penelitian ini adalah seluruh lansia yang berada di Kelurahan Melong sejumlah 150 orang. Sampel dalam penelitian ini adalah lansia yang mengalami stres di kelurahan melong dengan kriteria yang telah ditentukan oleh peneliti. Perhitungan sampel berdasarkan rumus besar sampel penelitian analitis numerik berpasangan menurut (Dahlan, 2013), yaitu sebagai berikut:

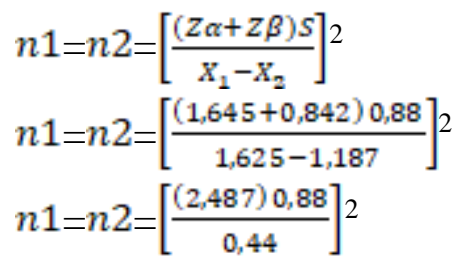


$n 1=n 2=\left[\frac{(2,188)}{0,44}\right]^{2}$
$n 1=n 2=[4,974]^{2}$
$n 1=n 2=24,74$ dibulatkan menjadi 25 sampel

Keterangan:

$Z \alpha=$ Deviasi baku alfa

$Z \beta=$ Deviasi baku beta

$\mathrm{S}=$ simpang baku dan selisih nilai antar kelompok

$\mathrm{X} 1-\mathrm{X} 2=$ selisihh minimal rerata yang dianggap bermakna

Kesalahan tipe I ditetapkan sebesar $10 \%$ hipotesis dua arah, sehingga $Z \alpha=$ 1,645. Kesalahan tipe II ditetapkan sebesar $20 \%$ maka $Z \beta=0,842$. Selisih minimal yang dianggap bermakna $(\mathrm{X} 1-\mathrm{X} 2)=0,44$ ini didapatkan dari hasil penelitian sebelumnya Hertanto K.Y (2014) yang berjudul Pengaruh Terapi Relaksasi Otot Progresif terhadap Tingkat Stres pada Lansia. Simpang bakunya adalah dua kali dari selisih rerata minimal yang dianggap bermakna, maka $\mathrm{S}=$ 0,88 .

Maka sesuai rumus diatas, jumlah sampel pada penelitian ini adalah 25 orang. Teknik pengambilan sampel yang digunakan dalam penelitian ini adalah concecutive sampling. Teknik ini di dasarkan pada suatu pertimbangan tertentu yang dibuat oleh peneliti berdasarkan kriteria-kriteria yang dapat memenuhi persyaratan sebagai sampel. Adapun kriteria yang ditentukan dalam penelitian ini meliputi:

a) Kriteria Inklusi

Kriteria Inklusi merupakan karakteristik umum subjek penelitian pada populasi yang terjangkau dan akan diteliti (Riyanto, 2011). Kriteria inklusi dalam penelitian ini yaitu :

1) Rentang usia $>60$ tahun

2) Telah dinilai tingkat stres dengan skala ukur PSS 10 minimal tingkat stres ringan.

3) Tidak terdapat gangguan pada ekstermitas diukur menggunakan NBP (Nordic Body Map).

4) Tidak terdapat gangguan kognitif diukur menggunakan Kuesioner MMSE minimal gangguan kognitif ringan.

5) Tidak terdapat gangguan pendengaran di ukur menggunakan garputala (tes rinne, weber, schwabach, tes bing, stenger) normal.

b) Kriteria Ekslusi

Kriteria ekslusi merupakan kriteria dari subjek penelitian yang tidak boleh ada dan harus dikeluarkan dari penelitian (Riyanto, 2011). Kriteria ekslusi dalam penelitian ini yaitu :

1) Kelompok lansia dengan gangguan jiwa 
2) Kelompok lansia dengan gangguan eliminasi (inkontinensia urine)

d. Instrumen Penelitian

Instrumen dalam penelitian ini adalah alat-alat yang digunakan untuk mengumpulkan data (Notoadmodjo, 2014). Penelitian ini menggunakan kuisioner untuk mengetahui tingkat stres pada lansia dengan menggunakan Perceived Stress Scale (PSS 10). Skor PSS diperoleh dengan reversing responses (sebagai contoh $0=4,1=3,2=2,3=1,4=0$ ) terhadap empat soal yang bersifat positif (pertanyaan 4,5,7,8).

a. Tidak pernah diberi skor 0

b. Hampir tidak pernah diberi nilai skor 1

c. Kadang-kadang diberi nilai 2

d. Cukup sering diberi nilai 3

e. Sangat sering diberi nilai 4

Semua penilaian diakumulasikan, kemudian disesuaikan dengan tingkat stres sebagai berikut :
a. Stres ringan (total skor 1-14)
b. Stres sedang (total skor $15-26$ )
c. Stres berat (tolat skor >26) (Cohen, Kamarck, \& Mermelstein, 1983).

e. Analisis data

Analisis data merupakan bagian yang sangat penting untuk mencapai tujuan pokok penelitian yaitu menjawab pertanyaan-pertanyaan penelitian yang mengungkap fenomena (Nursalam \& Sri, 2011). Analisis data dalam penelitian menggunakan analisis univariat dan analisis bivariat

f. Waktu dan tempat penelitian

Penelitian akan dilakukan di Kelurahan Melong pada bulan Oktober sampai desember 2020.

\section{Hasil dan Pembahasan}

\section{A. Hasil Penelitian}

Metode penelitian Quasi experiment pre test and post test design dalam penelitian ini digunakan untuk mengetahui pengaruh terapi relaksasi otot progresif terhadap tingkat stres pada lansia di Kelurahan Melong. Responden dalam penelitian ini berjumlah 25 responden dengan kriteria inklusi dan ekslusi yang telah ditetapkan sebelumnya. Penelitian ini dilakukan dengan cara wawancara dan menggunakan kuesioner. Kuesioner yang digunakan adalah Perceived Stress Scale-10. Teori yang digunakan dalam penelitian ini adalah The Psychologycal Stress Model (Lazarus \& Folkman, 1986). Pada penelitian ini dilakukan uji normalitas data dengan menggunakan Shapiro Wilk dan diperoleh hasil bahwa $\mathrm{P}_{\text {value }}$ pre test dan post test $(0,318$ dan 0,824$)>$ alpha 0,05 . Hal ini menunjukan bahwa distribusi data normal sehingga analisis bivariat menggunakan $t$ test dependen. Hasil penelitian pengaruh terapi relaksasi otot progresif terhadap tingkat stres pada lansia Kelurahan Melong adalah sebagai berikut. 


\section{Analisis Univariat}

Analisis univariat digunakan untuk mengetahui gambaran responden berdasarkan usia, jenis kelamin, tingkat stres; dan rata-rata tingkat stres sebelum dan sesudah diberikan terapi relaksasi otot progresif. Dimana karakteristik usia, jenis kelamin, tingkat stres dianalisis dengan menggunakan frekuensi dan presentase sedangkan rata-rata tingkat stres sebelum dan sesudah diberikan terapi relaksasi otot progresif dianalisis dengan menggunakan Mean, Standar Deviasi dan nilai minimum-maximum.

a. Gambaran Responden Berdasarkan Karakteristik Usia dan Jenis Kelamin Kelurahan Melong

Tabel 2

Gambaran Responden Berdasarkan Karakteristik Usia dan Jenis Kelamin Kelurahan Melong

\begin{tabular}{lcc}
\hline $\begin{array}{c}\text { Karakteristik } \\
\text { Responden }\end{array}$ & $\begin{array}{c}\text { Jumlah } \\
(\mathbf{n})\end{array}$ & $\begin{array}{c}\text { Presentase } \\
(\mathbf{\%})\end{array}$ \\
\hline & Usia & \\
\hline $60-70$ tahun & 6 & 24 \\
\hline $71-80$ tahun & 15 & 60 \\
\hline $81-90$ tahun & 4 & 16 \\
\hline Total & 25 & 100 \\
\hline & Jenis Kelamin & 52 \\
\hline Perempuan & 13 & 48 \\
\hline Laki-Laki & 12 & 100 \\
\hline Total & 25 & \\
\hline
\end{tabular}

Tabel 2 menunjukkan gambaran responden berdasarkan karakteristik usia dan jenis kelamin dengan jumlah responden pada penelitian ini adalah sebanyak 25 responden. Berdasarkan tabel diatas menunjukan bahwa terdapat sebagian besar (60\%) responden dengan kelompok usia 71-80 tahun. Sedangkan sebagian besar $(52 \%)$ responden adalah berjenis kelamin perempuan diikuti oleh responden berjenis kelamin laki-laki (48\%).

b. Gambaran Frekuensi Tingkat Stres Responden Sebelum dan sesudah dilakukan Terapi Relaksasi Otot Progresif Kelurahan Melong

Menurut (Cohen et al., 1983) Perceived Stress Scale-10 membagi tingkatan stres dalam 3 kategori, yaitu stres ringan (1-14), stres sedang (1525) dan stres berat (26-40).

Tabel 3

Gambaran Frekuensi Tingkat Stres Responden Sebelum dan Sesudah dilakukan Terapi Relaksasi Otot Progresif Kelurahan Melong

\begin{tabular}{ccc}
\hline Tingkat stres & Jumlah (n) & Presentase (\%) \\
\hline & Pretest & \\
\hline Ringan & 1 & 10 \\
\hline Sedang & 16 & 64 \\
\hline Berat & 8 & 32 \\
\hline Total & 25 & 100 \\
\hline & Posttest \\
\hline
\end{tabular}




\begin{tabular}{ccc}
\hline Ringan & 2 & 8 \\
\hline Sedang & 23 & 92 \\
\hline Berat & 0 & 0 \\
\hline Total & 25 & 100 \\
\hline
\end{tabular}

Tabel 3 menunjukkan gambaran frekuensi tingkat stres responden sebelum dilakukan terapi relaksasi otot progresif. Berdasarkan tabel diatas sebagian besar responden (64\%) mengalami stres sedang. Diikuti oleh responden dengan tingkat stres berat (32\%) dan stres ringan (10\%). Sedangkan frekuensi tingkat stres setelah dilakukan terapi relaksasi otot progresif hampir seluruhnya (92\%) responden memiliki tingkat stres sedang diikuti oleh responden yang memiliki tingkat stres ringan (8\%), dan tidak ada responden yang memiliki tingkat stres berat.

c. Gambaran Rata-rata Tingkat Stres Sebelum diberikan Terapi Relaksasi Otot Progresif pada Lansia Kelurahan Melong.

Tabel 4

Gambaran Rata-Rata Tingkat Stres Sebelum diberikan Terapi Relaksasi Otot Progresif pada Lansia Kelurahan Melong

\begin{tabular}{ccccc}
\hline Variabel & Mean & S.D & $\begin{array}{c}\text { Minimal- } \\
\text { Maksimal }\end{array}$ & $\mathbf{9 5 \%}$ CI \\
\hline Pretest & 23,84 & 3,682 & $14-30$ & $22,32-25,36$ \\
\hline
\end{tabular}

Hasil analisis pada tabel 4 didapatkan rata-rata (mean) tingkat stres sebelum dilakukan terapi relaksasi otot progresif adalah 23,84 (95\% CI: 22,32-25,36) dengan standar deviasi 3,682. Tingkat stres terendah yaitu 14, dan tingkat stres tertinggi yaitu 30. Dari estimasi interval disimpulkan bahwa 95\% diyakini rata-rata tingkat stres sebelum diberikan relaksasi otot progresif pada lansia Kelurahan Melong adalah diantara 22,32 sampai dengan 25,36.

d. Gambaran Rata-rata Tingkat Stres Sesudah diberikan Terapi Relaksasi Otot Progresif pada Lansia Kelurahan Melong.

Tabel 5

Gambaran Rata-Rata Tingkat Stres Sesudah diberikan Terapi Relaksasi Otot Progresif pada Lansia Kelurahan Melong

\begin{tabular}{ccccc}
\hline Variabel & Mean & S.D & $\begin{array}{c}\text { Minimal- } \\
\text { Maksimal }\end{array}$ & $\mathbf{9 5 \%}$ CI \\
\hline Posttest & 19,00 & 3,266 & $11-25$ & $17,65-20,35$ \\
\hline
\end{tabular}

Hasil analisis pada tabel 5 didapatkan rata-rata (mean) tingkat stres sesudah dilakukan relaksasi otot progresif adalah 19,00 (95\% CI: 17,6520,35) dengan standar deviasi 3,266. Tingkat stres terendah yaitu 11, dan tingkat stres tertinggi yaitu 25. Dari estimasi interval disimpulkan bahwa 
95\% diyakini rata-rata tingkat stres sesudah diberikan relaksasi otot progresif pada lansia Kelurahan Melong adalah diantara 17,65 sampai dengan 20,35.

\section{Analisis Bivariat}

Analisis bivariat digunakan untuk mengetahui Pengaruh Terapi Relaksasi Otot Progresif Terhadap Tingkat Stres pada Lansia Kelurahan Melong. Analisis dalam penelitian ini menggunakan $t$ test dependen, dimana $t$ test dependen itu mempunyai syarat kelompok yang diteliti harus sama dan data harus normal.

a. Pengaruh Terapi Relaksasi Otot Progresif Terhadap Tingkat Stres pada Lansia Kelurahan Melong.

Tabel 6

Perbedaan Rata-Rata Tingkat Stres Sebelum dan Sesudah Terapi Relaksasi Otot Progresif pada Lansia Kelurahan Melong.

\begin{tabular}{lccccc}
\hline \multicolumn{1}{c}{ Variabel } & Mean & SD & SE & $\begin{array}{c}\text { P } \\
\text { Value }\end{array}$ & N \\
\hline Tingkat Stres & & & & & \\
$\begin{array}{l}\text { Pretest } \\
\text { Posttest }\end{array}$ & 23,84 & 3,682 & 0,736 & 0,001 & 25 \\
\hline
\end{tabular}

Hasil analisis pada tabel 6 didapatkan bahwa rata-rata (mean) tingkat stres lansia sebelum diberikan terapi relaksasi otot progresif sebesar 23,84 dengan standar deviasi 3,682, dan standard eror 0,653. Sementara itu nilai rata-rata tingkat stres sesudah diberikan terapi relaksasi otot progresif adalah 19,00 dengan standar deviasi 3,266 dan standard eror 0,653. Hasil uji statistik menggunakan $T$-test dependen diperoleh $\mathrm{P}_{\text {value }}$ sebesar 0,001 . Hal ini berarti $\mathrm{P}_{\text {value }}<$ alpha $(0,05)$, artinya terdapat perbedaan antara tingkat stres sebelum dan sesudah diberikan terapi relaksasi otot progresif.

\section{B. Pembahasan}

Hasil penelitian sebelumnya telah dibahas mengenai data yang didapatkan oleh peneliti ketika meneliti di lapangan. Pada bagian kali ini, peneliti akan menguraikan hasil penelitian secara rinci yang juga disertai dengan referensi teori yang telah ada sebelumnya untuk memperkuat hasil penelitian yang didapat.

1. Rata-Rata Tingkat Stres Sebelum Diberikan Terapi Relaksasi Otot Progresif

Berdasarkan data yang didapatkan oleh peneliti sebelum diberikan terapi relaksasi otot progresif terdapat 1 responden mengalami stres ringan, 16 responden mengalami stres sedang dan 8 responden mengalami stres berat. Setiap responden memiliki tingkat stres yang berbeda-beda, hal ini disebabkan karena stres pada lansia dapat disebabkan oleh berbagai situasi kondisi sebagai akibat stresor yang berupa perubahan-perubahan baik fisik, mental, maupun sosial dalam keadaan yang dialami lansia dan karena stres bersifat subjektif dan dipengaruhi oleh berbagai faktor (Hertanto \& Suratini, 2014).

Didukung oleh teori (Laza rus \& Folkman, 1986) bahwa setiap orang memilliki respon yang berbeda dalam menghadapi stres. Respon terhadap segala 
bentuk stres bergantung pada fungsi fisiologis, kepribadian, serta sifat dari stresor. Seseorang yang mengalami stres akan menimbulkan keluhan-keluhan seperti mudah marah, tersinggung, murung cemas, sedih pesimis, mudah menangis, suasana hati sering berubah-ubah, mudah menyerah, mempunyai sikap bermusuhan. Apabila tidak diatasi dapat menimbulkan permasalahan yang harus dihadapi oleh lansia sehingga dapat mengakibatkan aktifitas sehari-hari terganggu dan kualitas hidup lansia yang menurun.

Stres adalah stimulus atau situasi yang menimbulkan distres dan menciptakan tuntutan fisik dan psikis pada seseorang. Stres membutuhkan coping dan adaptasi. Sindrom adaptasi umum atau teori Selye, menggambarkan stres sebagai kerusakan yang terjadi pada tubuh tanpa mempedulikan apakah penyebab stres tersebut positif atau negatif. Respons tubuh dapat diprediksi tanpa memerhatikan stresor atau penyebab tertentu (Hawari, 2006).

Menurut Selye stres adalah respon tubuh yang sifatnya nonspesifik terhadap setiap tuntutan beban atasnya. Bila seseorang setelah mengalami stres mengalami gangguan pada satu atau lebih organ tubuh sehingga yang bersangkutan tidak lagi dapat menjalankan fungsi pekerjaannya dengan baik, maka ia disebut mengalami distres. Pada gejala stres, gejala yang dikeluhkan penderita didominasi oleh keluhan-keluhan somatik (fisik), tetapi dapat pula disertai keluhan-keluhan psikis (Achdiat, 2003).

Menurut National Safety (Council, 2010) manajemen stres dapat dilakukan dengan beberapa cara, yaitu: keterampilan coping yang efektif, teknik relaksasi, dan gaya hidup yang lebih sehat.Manajemen stres ialah upaya yang rasional, terarah dan karenanya efektif untuk mengatasi stress. Upaya ini bersifat menyeluruh, dalam artian melibatkan baik mental maupun fisik bahkan sprit. Selain itu, manajemen stress juga menyangkut sisi pencegahan (preventive) maupun upaya penanganan (treatment). Upaya ini hanya mungkin efektif kalau dilaksanakan.

Mulyono (2005) menjelaskan beberapa keuntungan yang diperoleh dari latihan relaksasi diantaranya relaksasi membuat seseorang lebih mampu menghindari reaksi yang berlebihan karena adanya stres. keterampilan relaksasi sangat berguna untuk mengembangkan kemampuan tetap tenang atau menghindari stres saat menghadapi kesulitan, selalu rileksakan membuat seseorang memegang kendali hidup.

Melihat adanya efek negatif dari stres yang dapat membawa kerugian bagi setiap yang mengalaminya, maka perlu adanya manajemen stres. Manajemen stres merupakan upaya untuk mengendalikan stres namun tidak untuk menghilangkannya. Salah satu manajemen stres yang dapat dilakukan adalah dengan teknik relaksasi otot progresif (Hertanto \& Suratini, 2014). 


\section{Rata-rata Tingkat Stres Sesudah dilakukan Terapi Relaksasi Otot Progresif}

Berdasarkan teori yang disampaikan oleh (Hurlock, 1980) yang menyatakan bahwa bagi lansia yang berhasil dalam penyesuaian diri terhadap perubahan dan kemunduran yang dialaminya akan memunculkan perasaan dan sikap-sikap yang positif bagi dirinya maupun lingkungannya. Lansia akan terhindar dari stres karena memiliki perasaan masih tetap berguna, bijaksana, bahagia, mampu memanfaatkan waktu secara efektif dan efisien, melibatkan diri dengan aktivitas sosial, perasaan optimis, mengembangkan hobi, lebih religious (Hurlock, 1980).

Ketidak berhasilan lansia dalam melakukan penyesuaian diri terhadap semua perubahan yang dialami kaan memunculkan sifat-sifat negatif secara emosional, seperti mudah marah, mudah tersinggung, sering ngambek, suka bertengkar, ketakutan berlebihan, kecemasan yang berlebihan, serta perasaan tersiksa. Lansia yang mengalami kesepian, tidak berguna, keinginan untuk cepat mati, membutuhkan perhatian lebih, muncul rasa tersisih, merasa tidak dibutuhkan lagi, ketidakikhlasan menerima kenyataan baru seperti penyakit yang tidak kunjung sembuh merupakan beberapa masalah yang tidak enak dan potensial memunculkan stress (Nugroho, 2008).

Teknik relaksasi progresif ini sendiri mempunyai manfaat untuk mengatasi berbagai permasalahan dalam mengatasi berbagai permasalahan dalam mengatasi stres, kecemasan, insomnia dan juga dapat membangun emosi positif dari emosi negatif. Keempat permasalahan tersebut dapat menjadi suatu rangkaian bentuk gangguan psikologis bila tidak diatasi. Stres terhadap tugas maupun permasalahan lainnya, apabila tidak segera ditangani dapat memunculkan suatu bentuk kecemasan dalam diri seseorang, sehingga menimbulkan emosi yang negatif yang timbul akibat stres dan relaksasi dapat digunakan supaya seseorang kembali pada keadaan normal (Setyoadi, 2011).

Hasil penelitian ini sesuai dengan teori bahwa manfaat teknik relaksasi progresif dapat menurunkan ketegangan otot, kecemasan, insomnia, depresi,kelelahan, iritabilitas, spasme otot, nyeri leher, dan punggung, tekanan darah tinggi, fobia ringan (Setyoadi, 2011).

Terapi relaksasi progresif merupakan salah satu teknik relaksasi yang diberikan kepada lanjut usia yang dapat menenangkan pikiran dan melemaskan otot-otot yang kaku. Relaksasi progresif juga merupakan teknik latihan nafas yang teratur dan apabila dilakukan dengan benar tubuh akan menjadi rileks. Relaksasi progresif ini dilakukan mulai dari otot-otot dikaki, tangan, perut, dada dan wajah dengan cara menegangkan otot-otot tertentu kemudian melepaskan ketegangan tersebut. Setelah itu lanjut usia dapat merasakan keduanya pada saat otot dalam keadaan tegang dan rileks (Setyoadi, 2011).

Dari hasil penelitian ini, setelah diberikan terapi relaksasi otot progresif sebanyak 23 responden masuk dalam kategori stres sedang, 2 responden masuk 
kedalam kategori stres ringan dan tidak ada satu pun yang masuk ke dalam kategori stres berat.

Hal ini didukung oleh hasil wawancara setelah diberikan terapi relaksasi otot progresif ini bahwa lansia mengatakan badannya menjadi lebih segar, rileks dan tidak merasa tegang lagi. Salah satu lansia mengatakan sebelum dilakukan terapi relaksasi otot progresif, ia sering mengalami kesemutan di daerah persendian namun setelah diberikan terapi relaksasi otot progresif ini lansia tersebut mengatakan bahwa sudah jarang mengalami kesemutan lagi. Dari hasil pengamatan peneliti, perubahan yang signifikan adalah lansia yang tadinya biasa mengurung diri di kamar setelah diberikan terapi relaksasi otot progresif ini ia sudah bisa bergaul dengan teman-temannya.

Hasil penelitian ini sesuai dengan teori bahwa manfaat teknik relaksasi otot progresif dapat menurunkan ketegangan otot, kecemasan, insomnia, depresi, kelelahan, iritasi, spasme otot, nyeri leher dan punggung, tekanan darah tinggi dan fobia ringan (Setyoadi, 2011).

3. Pengaruh Terapi Relaksasi Otot Progresif Terhadap Tingkat Stres Pada Lansia Kelurahan Melong

Didapatkan bahwa rata-rata (mean) tingkat stres lansia sebelum dilakukan terapi relaksasi otot progresif adalah 23,84 dengan standar deviasi 3,682. Sedangkan tingkat stres sesudah dilakukan terapi relaksasi otot progresif adalah 19,00 dengan standar deviasi 3,266. Terlihat perbedaan antara nilai mean pada tingkat stres sebelum dan sesudah dilakukan terapi relaksasi otot progresif adalah 4,84 dengan standar deviasi 2,014. Hasil uji statistik dapat disimpulkan bahwa terdapat perbedaan yang signifikan antara rata-rata tingkat stres sebelum terapi relaksasi otot progresif dan sesudah terapi relaksasi otot progresif ( $p_{\text {value }}$ : $0,001 ; \alpha=0,05)$.

Dari hasil wawancara pada saat pretest 15 lansia mengatakan bahwa ia cukup sering marah karena sesuatu hal yang terjadi secara tiba-tiba namun pada saat posttest terdapat 2 lansia yang masih sering marah secara tiba-tiba dan sisanya mengatakan bahwa mereka sudah dapat mengatasi kesulitan yang berlipat-lipat di bandingkan sebelum diberikan terapi relaksasi otot progresif. Hal ini terbukti dari hasil kuesioner pretest bahwa sebagian besar lansia $(70,4 \%)$ mengatakan dirinya cukup sering tidak bisa mangatasi masalah-masalahnya namun pada saat postest sudah berkurang $(25,9 \%)$.

Christian berpandangan jika stres hanya bisa dikelola dengan manajemen stres merupakan upaya menyeluruh untuk mengendalikan stres namun tidak untuk menghilangkannya (Hurlock, 1980). Manajemen stres dengan teknik relaksasi merupakan salah satu teknik pengelolaan diri yang didasarkan pada cara kerja sistem saraf simpatis dan parasimpatis. Selain itu juga, ketika otot-otot sudah dirilekskan maka akan menormalkan kembali fungsi-fungsi organ tubuh. Setelah seseorang melakukan relaksasi dapat membantu tubuhnya menjadi 
rileks, dengan demikian dapat memperbaiki berbagai aspek kesehatan fisik (Yosep, 2009).

Di dalam sistem saraf manusia terdapat sistem saraf pusat dan sistem saraf otonom. Sistem saraf pusat berfungsi mengendalikan gerakan-gerakan yang dikehendaki, misalnya gerakan tangan, kaki, leher, dan jari-jari. Sistem saraf otonom berfungsi mengendalikan gerakan-gerakan yang otomatis, misalnya fungsi digestif, proses kardiovaskuler dan gairah seksual. Sistem saraf otonom ini terdiri dari dua subsistem yaitu sistem saraf simpatetis dan sistem saraf parasimpatetis yang kerjanya saling berlawanan. Jika sistem saraf simpatetis meningkatkan rangsangan atau memacu organ-organ tubuh, memacu meningkatnya denyut jantung dan pernafasan, serta menimbulkan penyempitan pembuluh darah tepi (peripheral) dan pembesaran pembuluh darah pusat, maka sebaliknya sistem saraf parasimpatetis menstimulasi turunnya semua fungsi yang dinaikkan oleh sistem saraf simpatetis dan menaikkan semua fungsi yang diturunkan oleh sistem saraf simpatetis (Council, 2010). Relaksasi otot progresif merupakan salah satu teknik manajemen stres yang cukup sering digunakan untuk menangani stres.

Relaksasi otot progresif menurut Jacobson adalah suatu keterampilan yang dapat dipelajari dan digunakan untuk mengurangi atau menghilangkan ketegangan dan mengalami rasa nyaman tanpa tergantung pada hal/subjek diluar dirinya. Relaksasi otot progresif ini digunakan untuk melawan rasa cemas, stres, atau tegang. Dengan menegangkan dan melemaskan beberapa kelompok otot dan membedakan sensasi tegang dan rileks, seseorang bisa menghilangkan kontraksi otot dan mengalami rasa rileks (Soewondo, 2009). Hal ini dikarenakan relaksasi otot progresif merupakan jenis relaksasi termurah, mudah untuk dilakukan secara mandiri.

Tujuan pokok teknik relaksasi adalah untuk menahan terbentuknya respon stres terutama dalam sistem saraf dan hormon. Pada akhirnya teknik relaksasi dapat membantu mencegah atau meminimalkan gejala fisik akibat stres ketika tubuh bekerja berlebihan dalam menyelesaikan masalah sehari-hari (National safety council, 2004).

Menurut (Setyoadi, 2011) teknik relaksasi otot progresif merupakan salah satu teknik untuk memelihara kesehatan fisik maupun psikologis pada lansia dimana teknik ini dapat menurunkan tekanan darah, menjadikan detak jantung tenang, dan menurunkan tingkat hormon stres.

Hal ini sesuai dengan teori yang menjelaskan beberapa keuntungan yang diperoleh dari latihan relaksasi otot progresif diantaranya membuat seseorang menjadi lebih mampu menghindari reaksi yang berlebihan karena adanya stres (Mulyono, 2005). Hal tersebut beriringan dengan hasil pretest bahwa sebanyak 12 lansia mengatakan mereka cukup sering mengalami gugup dan tertekan namun pada saat posttest hanya ada 6 lansia yang masih mengalami gugup dan 
tertekan. Dari hal tersebut dapat disimpulkan bahwa relaksasi otot progresif ini mampu menghindari reaksi yang berlebihan yang disebabkan oleh stres.

\section{Kesimpulan}

Berdasarkan hasil penelitian, analisis data dan pembahasan mengenai pengaruh terapi relaksasi otot progresif terhadap tingkat stres pada lansia Kelurahan Melong, dapat disimpulkan sebagai berikut: a). Rata-rata tingkat stres sebelum dilakukan terapi relaksasi otot progresif 23,84 . b). Rata-rata tingkat stres sesudah dilakukan terapi relaksasi otot progresif 19,00. c). Hasil uji statistik menunjukan terdapat pengaruh ratarata tingkat stres lansia sebelum dilakukan terapi relaksasi otot progresif dan sesudah terapi relaksasi otot progresif Kelurahan Melong ( $\mathrm{p}_{\text {value }}$ 0,001; a: 0,05) dengan selisih nilai mean sebelum dan sesudah dilakukan terapi relaksasi otot progresif sebesar 4,84 . 


\section{BIBLIOGRAFI}

Ashari, Rizqi Ganis. (2018). Memahami hambatan dan cara lansia mempelajari media sosial. Google Scholar

Cohen, Sheldon, Kamarck, Tom, \& Mermelstein, Robin. (1983). A global measure of perceived stress. Journal of Health and Social Behavior, 385-396. Google Scholar

Council, N. S. (2010). Manajemen Stres. Jakarta: Buku Kedokteran.

Dahlan, S. (2013). Besar Sampel dan Cara Pengambilan Sampel dalam Penelitian Kedokteran dan Kesehatan. Jakarta: Salemba Medika. Google Scholar

Depkes. (2013). Data dan Informasi Kesehatan. (diperoleh pada tanggal 03 Maret 2017). Retrieved from http://www.depkes.go.id

Depkes. (2016). Lansia Yang Sehat, Lansia Yang Jauh Dari Demensia (diperoleh pada tanggal 03 Maret 2017). Retrieved from http://www.depkes.go.id

Hertanto, Krisna Yudhi, \& Suratini, Suratini. (2014). Pengaruh Terapi Relaksasi Progresif terhadap Tingkat Stres pada Lanjut Usia di PSTW Yogyakarta Unit Budi Luhur. STIKES'Aisyiyah Yogyakarta. Google Scholar

Hidayati, Laili Nur. (2009). Hubungan dukungan sosial dengan tingkat depresi pada lansia di Kelurahan Daleman Tulung Klaten. Universitas Muhammadiyah Surakarta. Google Scholar

Hurlock, Elizabeth B. (1980). Psikologi perkembangan. Jakarta: Erlangga.

Kartinah, Kartinah, \& Sudaryanto, Agus. (2008). Masalah psikososial pada lanjut usia. Jurnal Berita Ilmu Keperawatan, 1(2), 93-96. Google Scholar

Lazarus, Richard S., \& Folkman, Susan. (1986). Cognitive theories of stress and the issue of circularity. In Dynamics of stress (pp. 63-80). Springer. Google Scholar

Mahfiroh, Intan. (2013). Hubungan pola aktivitas pemenuhan kebutuhan dasar dengan tingkat stres lanjut usia di panti sosial tresna werdha mulia dharma kabupaten kubu raya. Jurnal ProNers, 1(1). Google Scholar

Nasir, A. (2011). Dasar Dasar Keperawatan Jiwa. Jakarta: Salemba Medika.

Notoadmodjo. (2014). Prinsip dasar ilmu kesehatan Masyarakat. Jakarta: Rineka Cipta.

Nugroho, W. (2008). Perawatan Lanjut Usia. Jakarta: EGC.

Nursalam, Siti Pariani, \& Sri, U. (2011). Konsep dan penerapan metodologi penelitian ilmu keperawatan: pedoman skripsi. Doctoral dissertation, Tesis, dan Instrumen Penelitian Keperawatan. Jakarta .... Google Scholar 
Pengaruh Terapi Relaksasi Otot Progresif Terhadap Tingkat Stres pada Lansia Di RW 23 Kelurahan Melong

Riyanto, A. (2011). Aplikasi Metodologi Penelitian Kesehatan. Yogyakarta: Nuha Medika.

Setyoadi, \&. Herodes. (2011). Terapi Modalitas Keperawatan pada Klien Psikogeriatrik. Jakarta: Salemba Medika.

Sugiyono. (2017). Metode Penelitian Kuantitatif, Kualitatif, dan R\&D. Bandung: Alfabeta.

Suli, Didik Prasetyo, Aini, Nur, \& Prasetyo, Yoyok Bekti. (2019). Pengaruh green color breathing therapy terhadap penurunan tingkat stres pada pasien hemodialisa. Jurnal Keperawatan, 2(2), 86-96. Google Scholar

Wahyuni, Wahyuni, \& Ambarwati, Lucia. (2016). Relaksasi Otot Progresifsebagai Upaya Menurunkan Tingkat Depresi Lansia Di Posyandu Anggrek Desa Gandekan Wilayah Kerja Puskesmas Purwodiningratan Jebres Surakarta. Google Scholar

Yosep, I. (2009). Keperawatan Jiwa. Bandung: PT. Refika Aditama.

\section{Copyright holder:}

Khrisna Wisnusakti (2021)

First publication right:

Syntax Literate: Jurnal Ilmiah Indonesia

This article is licensed under:

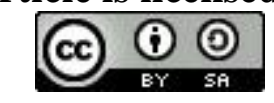

